\title{
BAYESIAN SPATIOTEMPORAL ANALYSIS OF RADIOCARBON DATES FROM EASTERN FENNOSCANDIA
}

\author{
Päivi Onkamo ${ }^{1,2}$ • Juhana Kammonen ${ }^{1}$ - Petro Pesonen ${ }^{1,3}$ - Tarja Sundell ${ }^{1,3}$ • \\ Elena Moltchanova ${ }^{4} \cdot$ Markku Oinonen $^{5} \cdot$ Miikka Haimila $^{6} \cdot$ Elja Arjas $^{7}$
}

\begin{abstract}
Archaeological phenomena, especially those that have been radiocarbon dated, can be utilized as indications of human activity and occupancy in space and time. ${ }^{14} \mathrm{C}$ dates from archaeological contexts have been used as proxies for population history events in several recent studies (e.g. Gamble et al. 2005; Shennan and Edinborough 2007; Oinonen et al. 2010; Tallavaara et al. 2010; Pesonen et al. 2011). As a step towards a larger spatiotemporal modeling effort, we present examples of spatial distributions obtained using Bayesian methodology, analyzing all available archaeological ${ }^{14} \mathrm{C}$ dates from the Stone Age (9000-1500 cal BC) in eastern Fennoscandia. The resulting maps follow the patterns of pioneer settlement in Finland beginning at $\sim 9000 \mathrm{cal} \mathrm{BC}$ and provide supporting evidence for the postulated population peak around $4000-3500 \mathrm{cal} B C$ in Finland and the subsequent population decline.
\end{abstract}

\section{INTRODUCTION}

Recently, compilations of radiocarbon dates from archaeological contexts have been utilized as proxies for population history events (e.g. Gamble et al. 2005; Ortman et al. 2007; Shennan and Edinborough 2007; Oinonen et al. 2010; Tallavaara et al. 2010; Pesonen et al. 2011) and ecological processes (Macklin et al. 2010; Reyes and Cooke 2011). However, the data have typically not been analyzed in a spatial statistical framework (except for Ortman et al. 2007), but rather as cumulative probability density functions of calibrated ${ }^{14} \mathrm{C}$ dates belonging to a specific period and large geographical areas (such as Alaska, circum-Arctic, southwest Europe vs. northwest Europe). Here, we present our effort in analyzing the spatial dimension of archaeological ${ }^{14} \mathrm{C}$ dates, utilizing Bayesian hierarchical methodology for small area analysis, originally constructed for image restoration (Besag et al. 1991) and widely used in epidemiology (e.g. Karvonen et al. 2002; Moltchanova et al. 2004; Best et al. 2005; Bilancia and Fedespina 2009) and ecology (e.g. Heikkinen and Högmander 1994; Sims et al. 2008). We chose to use the Besag-York-Mollie (BYM) model because it is widely applied in modeling the geographical distribution of rare events (i.e. data indexed at a small geographical resolution, and thus sparse by nature). Essentially, the model has been shown to be robust despite the sparsity of the data (Best et al. 2005).

Ortman et al. (2007) present an approach where the relationship between small-scale surface evidence and excavation results are translated in a framework inspired by Bayesian inference, in order to reconstruct settlement patterns from survey data. Compared to Ortman et al. (2007), our focus is on a larger geographical scale, describing the overall spatial variation in human activity.

There is an abundance of archaeological sites indicating past human activity in eastern Fennoscandia, 40,000 in total. Detailed information on nearly all of the archaeological finds has been recorded into a national database: Registry of Ancient Monuments (RAM, Muinaisjäännösrekisteri in Finnish). One of the goals of our Argeopop project (http://www.helsinki.fi/bioscience/argeopop) is to

\footnotetext{
${ }^{1}$ Department of Biosciences, University of Helsinki, Finland.

${ }^{2}$ Corresponding author. Email: paivi.onkamo@helsinki.fi.

${ }^{3}$ Department of Philosophy, History, Culture and Art Studies, University of Helsinki, Finland.

${ }^{4}$ Department of Mathematics and Statistics, University of Canterbury, Christchurch, New Zealand.

${ }^{5}$ Finnish Museum of Natural History, Dating Laboratory, University of Helsinki, Finland.

${ }^{6}$ National Board of Antiquities, Helsinki, Finland.

${ }^{7}$ Department of Mathematics and Statistics, University of Helsinki, Finland.
}

(c) 2012 by the Arizona Board of Regents on behalf of the University of Arizona Proceedings of the 6th International Radiocarbon and Archaeology Symposium, edited by E Boaretto and N R Rebollo Franco RADIOCARBON, Vol 54, Nr 3-4, 2012, p 649-659 
augment this database by complementing information on artifacts and archaeological sites. Typologically identifiable artifacts are documented and their exact find location is verified. The ongoing work already allows ${ }^{14} \mathrm{C}$-dated parts of the data to be utilized in preliminary statistical analyses. We focused on the time interval 9000-1500 cal BC, i.e. the Mesolithic and Neolithic Stone Age in Finland. A total of 820 archaeological ${ }^{14} \mathrm{C}$ dates from eastern Fennoscandia (Finland and ceded Karelia, ${ }^{8}$ Figure 1) fall into this period. Each date was interpreted as evidence of human activity during the time. The study interval was divided into 6 subintervals, with the goal of presenting an overview of the variation in the intensity of human activity in time and space. The results shed additional light on many of the characteristics of interest of the population history of eastern Fennoscandia.

\section{MATERIALS AND METHODS}

\section{The Data}

The ${ }^{14} \mathrm{C}$ data consists of 820 dates from $9000-1500$ cal BC (Figure 1) and form a subset of a larger data set of 2565 dates (Oinonen et al. 2010; Tallavaara et al. 2010 and references therein). The ${ }^{14} \mathrm{C}$ analyses performed at the Dating Laboratory (Finnish Museum of Natural History, University of Helsinki) form the backbone of the data used. The data set was extended to cover-as thoroughly as possible-the other published archaeological ${ }^{14} \mathrm{C}$ dates from eastern Fennoscandia measured either at the Dating Laboratory or elsewhere. In addition, the data also contain those unpublished dates that have been kindly released for our use by the customers of the Dating Laboratory. The whole data set has been scrutinized (see Oinonen et al. 2010; Tallavaara et al. 2010). The present data are dominated by charcoal finds: $56 \%$ are from charcoal dates. Charred crust samples from pottery represent another large fraction of dated material, amounting to $14 \%$. The remaining material consists mostly of samples of burnt bone (8\%) or birch bark tar $(6 \%)$.

The calibration has been carried out with CalPal software (Weninger and Jöris 2004), which uses the IntCal04 calibration curve (Reimer et al. 2004). The period 9000-1500 cal BC was split into 6 intervals, according to the "traditional" Finnish chronology: 9000-6400 cal BC (Early and Middle Mesolithic Stone Age); 6400-5100 cal BC (Late Mesolithic); 5100-4000 cal BC (Early Combed Ware period); 4000-3500 cal BC (Typical Combed Ware period); 3500-2500 cal BC (Late Combed Ware and Corded Ware period); and 2500-1500 cal BC (Late Subneolithic) (generalized from e.g. Carpelan 1999, 2002). The dates were assigned into these time periods based on the posterior mean as estimated by CalPal. We therefore treat these estimates as data and ignore any uncertainty associated with them. This is, indisputably, a simplification.

\section{The Model}

The maps (of posterior means) in this work were produced using a Bayesian hierarchical methodology for small area analysis, using a slight modification of the Besag-York-Mollie (BYM) model (Besag et al. 1991). We divided the combined territory of Finland and ceded Karelia into $10 \times 10 \mathrm{~km}$ cells, thereby forming a grid numbering 3997 cells. Considering separately each of the 6 time periods, and indexing the grid cells by $i$, each cell $i$ was assigned a response variable $Y_{i}$, which was defined as follows: $Y_{i}=1$ if the data contained at least 1 find from this cell, which had been dated to the considered time period, and $Y_{i}=0$ if the data contained at least 1 find from this cell, but none that would belong to the considered time period. For cells $i$ from which there were no ${ }^{14} \mathrm{C}$-dated finds, the value of the response variable $Y_{i}$ was considered as missing (NA), and then treated as a random variable, applying the method of data augmentation.

${ }^{8}$ Ceded Karelia refers to the region southeast of the current borders of Finland, which was part of the country before The Moscow Armistice signed between Finland and Soviet Union in 1944. 


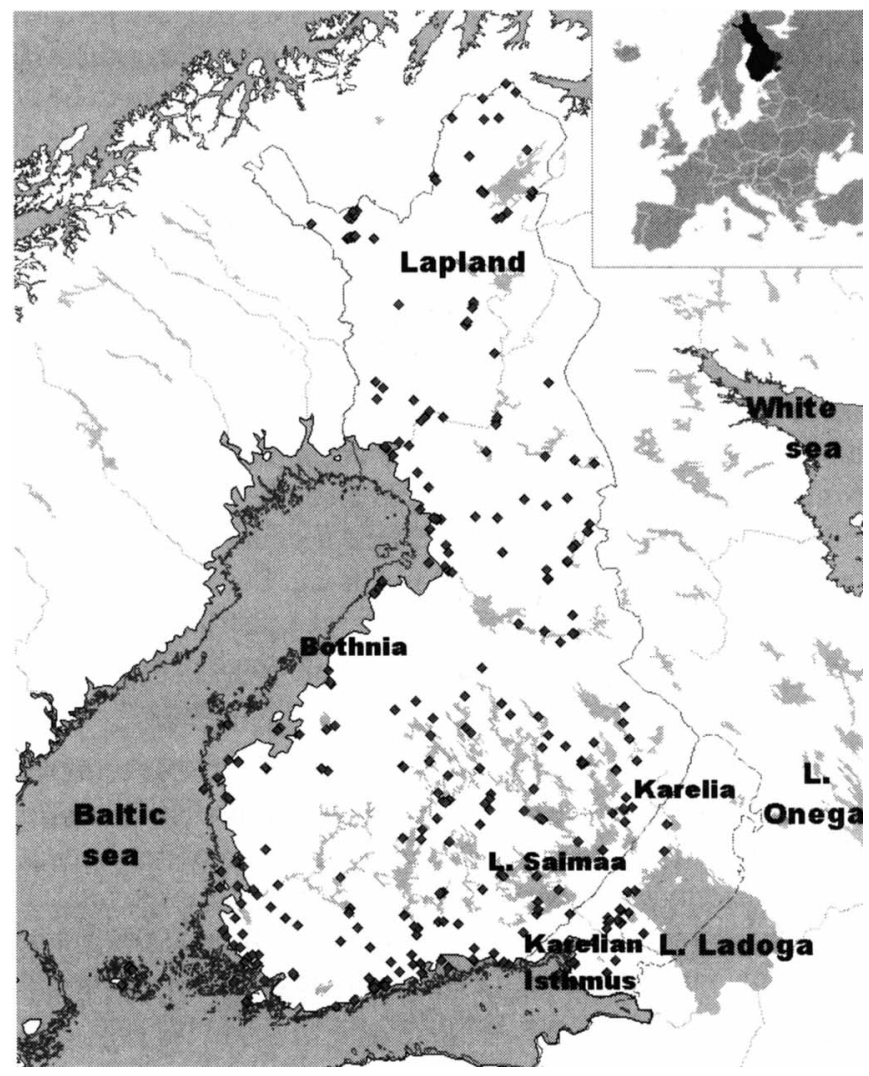

Figure 1 Upper right inset: Finland (black) and ceded Karelia (dark gray), northern Europe). The big map: Locations of archaeological finds that have been ${ }^{14} \mathrm{C}$ dated (green diamonds, $n=820$ ) from Finland and ceded Karelia, and which are used in this study. A few territory names are provided for reference. Some date locations overlap; thus, there are less than $820{ }^{14} \mathrm{C}$-dated locations shown.

The hierarchical Bayesian model used in this work is structured as follows:

$$
\begin{gathered}
Y_{i} \sim \operatorname{Bernoulli}\left(\pi_{i}\right) \\
\operatorname{logit}\left(\pi_{i}\right)=\alpha+\lambda_{i} \\
\alpha \sim N(m, 1) \\
\lambda_{i} \sim \operatorname{CAR}(\tau, \text { weights })=N\left(\lambda_{-i}, \sigma^{2}\right)
\end{gathered}
$$

Here, the parameter $\pi_{i}$ can be viewed as the "chance of cell $i$ being occupied." It is modeled by logistic regression, by decomposing logit $\left(\pi_{i}\right)$ into a global baseline parameter $\alpha$ and an area-specific random effect $\lambda_{i}$. In the execution of our data analysis, various relatively vague prior distributions were assigned for $\alpha$, thereby testing the sensitivity of the results to such particular specifications. In absence of more information and clear alternatives, we ended up calibrating our model empirically, letting $m$ be equal to the value $\log \operatorname{it}(\hat{p})=\log (\hat{p} /(1-\hat{p}))$ where $\hat{p}$ is the observed relative frequency, during the considered time period, of cells $i$ with $Y_{i}=1$ among those with either $Y_{i}=1$ or $Y_{i}$ $=0$. In this respect, the results reported below can be said to be empirical Bayesian. 
The joint distribution of the random effects $\left(\lambda_{i}\right)$, representing the spatial correlation of the local response variables $Y_{i}$, is then defined in terms of the conditional autoregressive (CAR) model (Besag et al. 1991). According to that model, the local random effect $\lambda_{i}$ is taken to be normally distributed, with expectation equal to the mean of the corresponding random effects in the neighborhood of cell $i$ (without including cell $i$ itself), and with variance $\sigma^{2}$ (the inverse of the spatial precision $\tau$ ). Apart from cells forming the outer border of the mapped geographical area, there are 8 such neighbors for each cell.

The motivation, and rationale, behind using the CAR model is that of "borrowing strength" from the corresponding data in the neighboring cells (Besag et al. 1991). In other words, if a cell were occupied in the sense that at least 1 find from the considered time period fell into it, then it would be thought as more likely that a cell adjacent to it is also occupied. Note that by "being occupied" we mean that an item from the time period in question in a cell has been preserved through time, and finally found. For the time being, we do not take into account the potential taphonomic factors affecting the survival of the archaeological signal (as in e.g. Surovell and Brantingham 2007), the most significant being the transgressions in the Finnish lake district caused by the postglacial land uplift. It is also obvious that a part of the archaeological heritage of the Finnish lake district from $\sim 8000-4000 \mathrm{cal} \mathrm{BC}$ is under-represented in the archaeological database.

The model was estimated using the WinBUGS software (Lunn et al. 2000). WinBUGS utilizes Markov chain Monte Carlo sampling to estimate the model parameters. A single Markov chain with a burn-in of 5000 iterations and a further 15,000 iterations for monitoring was used. The convergence of the chain was verified by visual inspection. There were 6 runs in total, 1 for each time interval. Posterior means for the chance parameter $\pi_{i}$, as well as $10 \%$ and $90 \%$ quantiles of the posterior distribution, were plotted on a map of eastern Fennoscandia (Finland and ceded Karelia), Figure 2. The data was processed using R-software (http://cran.r-project.org) and visualized with Pitney Bowes Business Insight's (http://www.pbinsight.com) MapInfo 8.5. The larger values of the expectations can generally be interpreted as corresponding to more certain, or higher intensity of, human activity. The shorelines of the Baltic Sea corresponding to the different time intervals have been estimated with the shoreline model by Påsse and Daniels (2011) and the Geological Survey of Sweden.

\section{RESULTS AND DISCUSSION}

\section{Model}

The autoregressive model of Besag et al. (1991) has been applied successfully in many areas of scientific research where the geographical distribution of objects or structures that are not directly observed in the data is of interest. Here, its use is motivated, in particular, by the relatively sparse data consisting of $820{ }^{14} \mathrm{C}$-dated finds, divided further into 6 time intervals and then distributed among altogether 3997 grid cells. Our goal was to find a way in which such sparse point-set data could, by means of a statistical model, be converted to form a reasonable description of the spatial distribution of human activity during the considered time period.

One should note that the model used here is merely one particular choice among many alternatives that could have been used. In particular, instead of considering binary response variables we could have taken $Y_{i}$ to designate the actual number of finds in a cell that were dated to a given time period, and then modeled its behavior, for example, in terms of an inflated Poisson distribution. We aim to consider all finds $\left({ }^{14} \mathrm{C}\right.$ dated or not) in our future work, and then a response variable of this type appears to be more appropriate. Generalizing our work into a different direction, the major waterways and land routes could also be taken into account in future analyses, by redefining the concept 
of neighborhood to reflect the relative ease of moving along such pathways (cf. McColl 2008). An excellent archaeological discussion on ridges as routes of transportation is given in Holmblad (2010).

\section{Data}

There are several possible biasing factors within the data that need to be discussed. First of all, we have relied on the archaeological scrutiny under the sample selection to establish a link between the dated sample and the archaeological context. Therefore, no further exclusive selections were made. In a previous work by Oinonen et al. (2010), the temporal distributions of the ${ }^{14} \mathrm{C}$ dates were analyzed, in particular. According to the analyses, the shape of the temporal distribution of the uncalibrated ${ }^{14} \mathrm{C}$ data remained nearly unchanged decade by decade from the early days of the ${ }^{14} \mathrm{C}$ method in the area (1970s) to the last decade (2000s). Thus, it seems that the possible systematic biases due to the older - and therefore possibly more unreliable - dates have been modest. In addition, judging on the robust pattern of temporal distributions along with the decades, there have not been significant changes in research interests.

Such an analysis, however, does not rule out individually biased dates that are more difficult to be identified, but show the effect of older dates being more or less canceled out. These older ${ }^{14} \mathrm{C}$ dates possess larger statistical uncertainties $(\sim 100 \mathrm{yr})$ compared to the present data $(30-40 \mathrm{yr})$ and one may argue that some of the possible systematic biases may fall within these larger uncertainties. They, in turn, result in wider posterior probability distributions of calibrated ages.

Correction procedures for the 2 largest subsets of material, charcoal/wood and charred crust, can be implemented. An estimate for charcoal/wood own age of $\sim 50 \pm 80{ }^{14} \mathrm{C}$ yr was obtained by comparing the shapes of the time distributions of the ${ }^{14} \mathrm{C}$ ages of charcoal/wood and short-lived sample materials (Oinonen et al. 2010). This provides a guideline for the possible correction of wood/charcoal. In addition, Pesonen et al. (these proceedings) discuss reservoir effect corrections for charred crust samples and propose a corresponding correction procedure. In the other sample materials with shares of $5 \%$ or more, burnt bone samples of marine origin may have marine carbon incorporated. All these factors will be dealt with in our future model development although not yet implemented. We assume the largest effects within the period of $6400-5100 \mathrm{cal} \mathrm{BC}$, since the period is strongly dominated by charcoal finds $(70 \%)$.

The calibrated dates have been categorized into certain periods of time based on the posterior mean as estimated by CalPal. We therefore treat these estimates as data and, for the time being, ignore any uncertainty associated with them. Naturally, the credible interval for a calibrated date may span 2 consecutive periods. Thus, the find belongs to each of the two with some probability $p<1$. Accounting for this uncertainty within the Bayesian framework is certainly possible, and we intend to return to this issue in the future.

\section{Archaeological Interpretations}

In general, the maps (Figure 2) comply with the pre-existing archaeological understanding, with some exceptions. The earliest ${ }^{14} \mathrm{C}$ dates from the pioneer settlement sites are around $8900 \mathrm{cal} \mathrm{BC}$ in eastern Finland. For the Mesolithic, the division to 2 periods was taken from Matiskainen (1989), who uses the terms Ancylus- and Litorina-Mesolithic derived from the successive phases of the Baltic Sea. Here, we call the earlier period (9000-6400 cal BC), the Early and Middle Mesolithic and the later period (6400-5100 cal BC), the Late Mesolithic. Concerning the Neolithic era, the time periods indicate the use of certain ceramic types. In the following, we discuss the present archaeological interpretation with respect to the maps we produced. 
$9000-6400$ cal BC, $10 \%$ quantile

posterior mean

$90 \%$ quantile
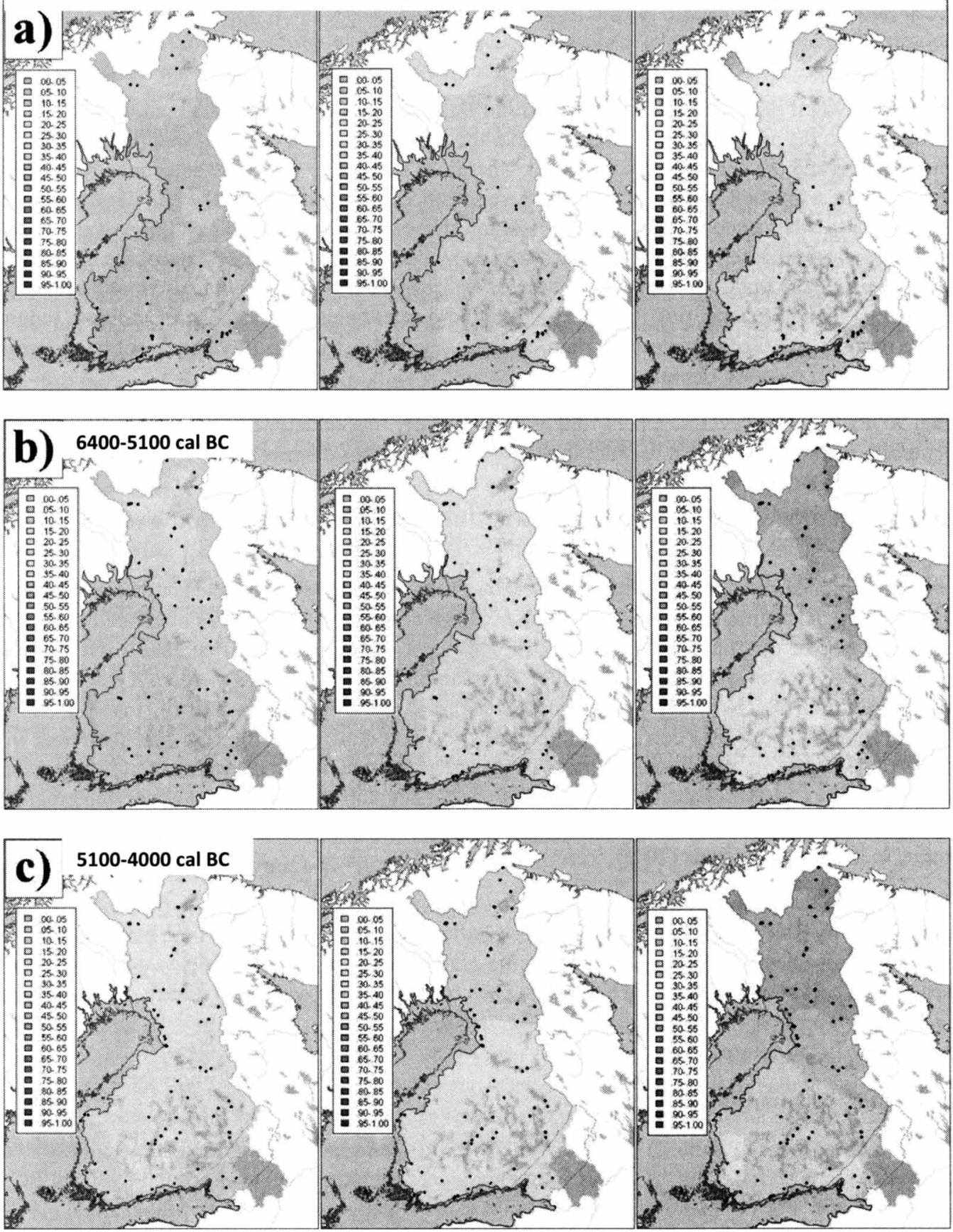

Figure 2 Spatial distributions of posterior means of $\pi_{i}$ (the chance of cell $i$ being occupied) in the middle of each map, with the $10 \%$ quantile (left) and $90 \%$ quantile (right). The gray dots denote locations of the finds dated to each period:

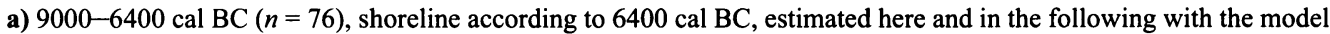
by Påsse and Daniels (2011) and Geological Survey of Sweden; b) 6400-5100 cal BC ( $n=106)$, shoreline 5100 cal BC; c) $5100-4000 \mathrm{cal} \mathrm{BC}(n=150)$, shoreline $4000 \mathrm{cal} \mathrm{BC}$. 

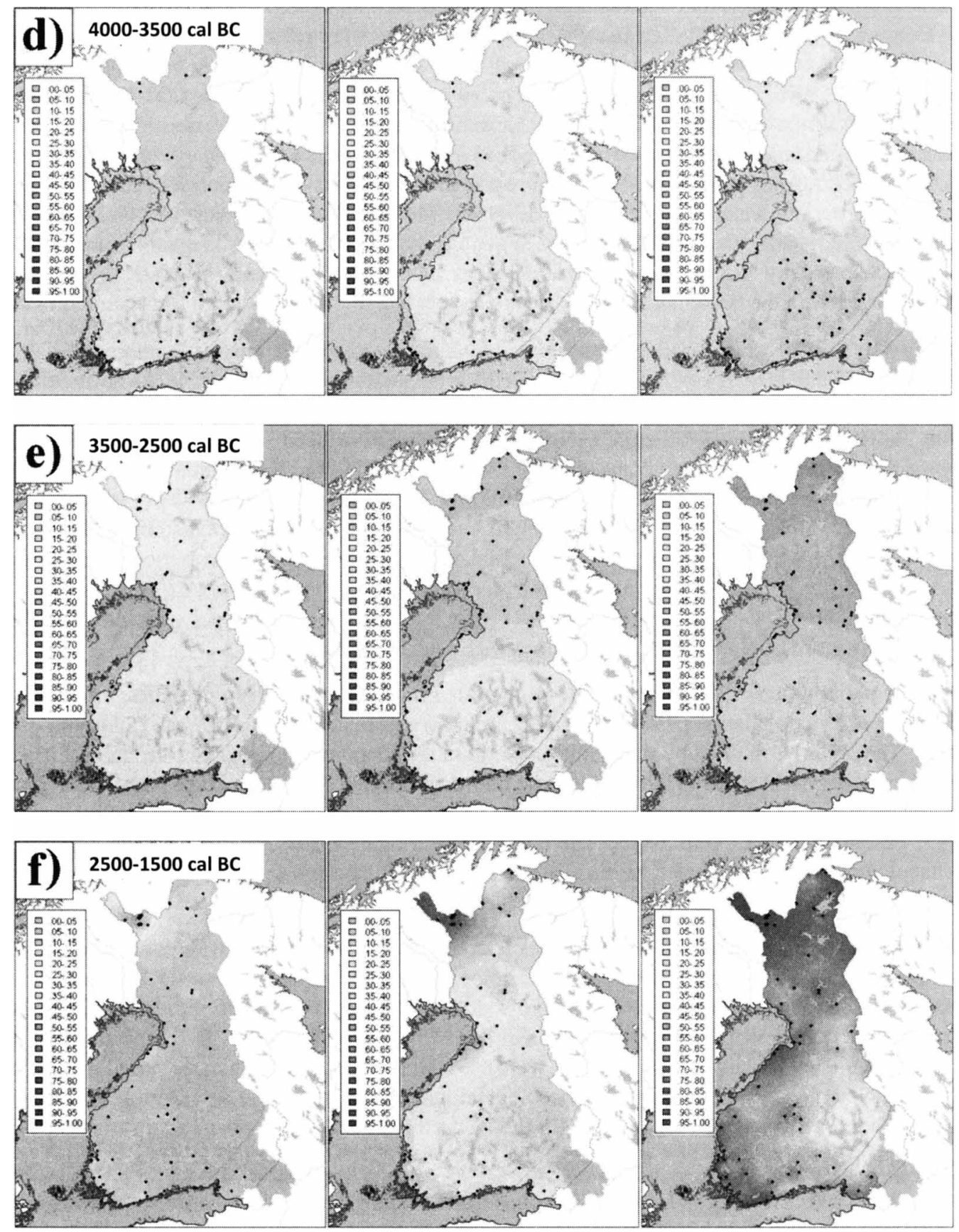

Figure 2 Continued d) $4000-3500 \mathrm{cal} \mathrm{BC}(N=187)$, shoreline $3500 \mathrm{cal} \mathrm{BC;} \mathrm{e)} 3500-2500 \mathrm{cal} \mathrm{BC}(n=187)$, shoreline $2500 \mathrm{cal} \mathrm{BC}$; f) $2500-1500 \mathrm{cal} \mathrm{BC}(n=124)$, shoreline $1500 \mathrm{cal} \mathrm{BC}$. When interpreting the maps, note that the time periods are not equally long. 
Archaeologically, it is evident that eastern Fennoscandia was populated very soon after the retreat of the Continental Ice Sheet. The earliest ${ }^{14} \mathrm{C}$ dates from archaeological sites date this pioneer settlement to $\sim 8900$ cal BC in eastern Finland (e.g. Takala 2004; Pesonen 2005; Jussila et al. 2007; Pesonen et al., forthcoming). The initial settlers came from the south and east (Meinander 1984; Huurre 1990; Carpelan 1999). It has been possible to trace 2 routes of colonization, one via the Karelian Isthmus and the other following the land route between the lakes Onega and Ladoga (see Figure 1). The map of posterior means (Figure 2a) shows an even distribution for the whole study area for this period, while during the Late Mesolithic (6400-5100 cal BC) northern Finland seems to be populated more densely than southern Finland (Figure $2 b$ ). The overall signal of human presence is distorted by the known lack of ${ }^{14} \mathrm{C}$ dates in the coastal areas: there are several Late Mesolithic sites on the Bothnian coast, which are not present in the ${ }^{14} \mathrm{C}$ data (cf. Matiskainen 1989).

During 5100-4000 cal BC, pottery was adopted by hunter-gatherers of eastern Fennoscandia. Two lines of ceramic traditions entered Finland from the east: Säräisniemi 1 ceramics in the northeast and Sperrings 1 and 2 ceramics in the southeast (e.g. Carpelan 1999; Torvinen 2000; German 2009). Note that the chronologies of these early ceramic styles have been re-estimated by a Bayesian approach (Pesonen et al., these proceedings). The area of admixture was eventually formed in the Kainuu-North Ostrobothnia region. The distribution of ${ }^{14} \mathrm{C}$-dated finds (gray dots in Figure $2 \mathrm{c}$ ) correspond well to archaeological knowledge, with 2 exceptions: the Finnish lake district and the Bothnian coast in the west. The lakes in eastern Finland, especially Saimaa, have experienced transgressions during the Holocene, which have buried shorebound settlement sites in large areas (e.g. Saarnisto 1971). The map for this time period (Figure 2c) presents a stronger signal in northern than southern Finland visualized already in the previous, Late Mesolithic, era.

The time period 4000-3500 cal BC, coinciding with Typical Combed Ware ceramics, has recently been posited as a population peak period in the prehistory of eastern Fennoscandia (Tallavaara et al. 2010). The period is marked by substantial changes in the economy, material culture, and society of the tribes living in the area, e.g. in the building tradition, import of exotic materials, and burial practice including signs of hierarchy (e.g. Vuorinen 1982; Meinander 1984; Carpelan 1999; Halinen 1999; Pesonen 2002; Edgren 2007). The map of posterior means (Figure 2d) reflects the strong archaeological signal designated to this phase in southern Finland and deviates from the more northern emphasis assessed in the previous eras (Figures $2 b$ and $2 c$ ).

The period of Typical Combed Ware was characterized by a uniform cultural roof, but gradually, it was broken down into local styles and technologies. Several separate ceramic traditions were formed in eastern Fennoscandia. During the period 3500-2500 cal BC, Late Combed Ware, Pyheensilta Ware, Kierikki Ware, Pöljä Ware, and Corded Ware were introduced. In the north, only the asbestos-tempered Kierikki and Pöljä Ware were used, while the south saw a more varied succession of styles. Nevertheless, according to archaeological knowledge, no area was depopulated entirely. The map of posterior means (Figure 2e) shows how northern Finland resurfaced again after the Typical Combed Ware period.

The period 2500-1500 cal BC marks the end of the Neolithic Stone Age in eastern Fennoscandia. The transition to the Bronze Age began, along with a major change in economy, especially in the coastal areas. Until that time, the signs of agriculture had been quite modest, although clearly present at least from the Typical Combed Ware period onwards (Mökkönen 2010). The settlement is concentrated along the coastal areas and is reflected in the archaeological record by Kiukais Ware and to some extent at the beginning of the period also by Corded Ware. Lapland and southwest Finland are now highlighted in the map of posterior means (Figure 2f). Eastern Finland is almost devoid 
of ${ }^{14} \mathrm{C}$ dates, which we argue can be considered a sign of a population bottleneck. A population bottleneck is a demographic phenomenon where the population size declines substantially as a result of an event such as famine, epidemic, war, or deterioration of environmental conditions. Such an event, especially in eastern Finland, has previously been proposed by Lavento (2001) and Sundell et al. (2010), and is thus further substantiated. Bottlenecks, especially narrow ones, significantly reduce the genetic diversity of a population and additionally can drift sporadic genes into high frequencies-such as the genes behind The Finnish Disease Heritage (FDH, http://www.findis.org). A subarea-specific bottleneck might also have contributed to the well-known genetic distinction between eastern and western Finnish populations (e.g. Kittles et al. 1998; Salmela et al. 2008; McEvoy et al. 2009; Palo et al. 2009).

\section{CONCLUSIONS}

The methodology presented provides technically sound systematic tools for spatial Bayesian analysis of archaeological data. The obtained results support many known characteristics of the population history of eastern Fennoscandia. Particularly, both the eastern and northern early stages of populations are highlighted and the emphasized role of the Typical Combed Ware culture is illustrated. The low posterior mean values of eastern Finland within the period 2500-1500 cal BC may be connected with the proposed population bottleneck in the area.

Updated archaeological databases will be available for use in the near future. It would be intriguing to utilize data about dwelling sites, typologically datable artifacts, and even geographical information (water routes, ridges) in the analysis to further investigate the background and geographical patterns of ancient human activity. The proposed Bayesian methodology provides a sound framework for such an extension of studies.

\section{REFERENCES}

Besag J, York J, Mollié A. 1991. Bayesian image restoration, with two applications in spatial statistics. Annals of the Institute of Statistical Mathematics 43:1-59.

Best N, Richardson S, Thomson A. 2005. A comparison of Bayesian spatial models for disease mapping. Statistical Methods in Medical Research 14:35-59.

Bilancia M, Fedespina A. 2009. Geographical clustering of lung cancer in the province of Lecce, Italy: 19922001. International Journal of Health Geographics 8: 40, doi:10.1186/1476-072X-8-40.

Carpelan C. 1999. Käännekohtia Suomen esihistoriassa aikavälillä 5100-1000 eKr. In: Fogelberg P, editor. Pohjan poluilla. Suomalaisten juuret nykytutkimuksen mukaan. Bidrag till kännedom av Finlands natur och folk [Societas Scientarum Fennica] 153:249-80.

Carpelan C. 2002. Esihistorian vuosiluvut, ajoitukset ja kronologia. In: Grünthal R, editor. Ennen muinoin. Miten menneisyyttämme tutkitaan 180 . Suomalaisen Kirjallisuuden Seura. p 18-27.

Edgren T. 2007. On the non-megalithic mortuary practices in Finland. In: Larsson L, Lüth F, Terberger T, editors. Innovation and Continuity - Non-Megalithic Mortuary Practices in the Baltic. New Methods and Research into the Development of Stone Age Society. Bericht der Römisch-Germanischen Kommission 88. p 501-20.
Gamble C, Davies W, Pettitt P, Hazelwood L, Richards M. 2005. The archaeological and genetic foundations of the European population during the Late Glacial: implications for 'agricultural thinking.' Cambridge Archaeological Journal 15(2):193-223.

German K. 2009. Early hunter-gatherer ceramics in Karelia. In: Jordan P, Zvelebil M, editors. Ceramics before Farming. The Dispersal of Pottery among Prehistoric Eurasian Hunter-Gatherers. University College London: London Institute of Archaeology Publications. p 255-80.

Halinen P. 1999. Burial practices and the structure of societies during the Stone Age in Finland. In: Huurre $M$, editor. Dig it All. Papers Dedicated to Ari Siiriäinen. Helsinki: The Finnish Antiquarian Society, the Archaeological Society of Finland. p 173-80.

Heikkinen J, Högmander H. 1994. Fully bayesian approach to image restoration with an application in biogeography. Journal of the Royal Statistical Society. Series C (Applied Statistics) 43:569-82.

Holmblad P. 2010. Coastal communities on the move. House and polity interaction in southern Ostrobothnia $1500 \mathrm{BC}-\mathrm{AD} 1$ [PhD thesis]. Umeå University.

Huurre M. 1990. 9000 vuotta Suomen esihistoriaa. Keuruu: Otava.

Jussila T, Kriiska A, Rostedt T. 2007. The Mesolithic set- 
tlement in NE Savo, Finland. Acta Archaeologica 78: 143-62.

Karvonen M, Moltchanova E, Viik-Kajander M, Moltchanov V, Rytkönen M, Kousa A, Tuomilehto J for the SPAT study group. 2002. Regional inequality in the risk of acute myocardial infarction (AMI) in Finland. Heart Drug 2:51-60.

Kittles RA, Perola M, Peltonen L, Bergen AW, Aragon RA, Virkkunen M, Linnoila M, Goldman D, Long JC. 1998. Dual origins of Finns revealed by Y chromosome haplotype variation. American Journal of $\mathrm{Hu}$ man Genetics 62(5):1171-9.

Lavento M. 2001. Textile ceramics in Finland and on the Karelian Isthmus. Nine variations and fugue on a theme of C. F. Meinander. Suomen Muinaismuistoyhdistyksen Aikakauskirja 109. Helsinki.

Lunn DJ, Thomas A, Best N, Spiegelhalter D. 2000. WinBUGS - a Bayesian modelling framework: concepts, structure, and extensibility. Statistics and Computing 10:325-37.

Macklin MG, Jones AF, Lewin J. 2010. River response to rapid Holocene environmental change: evidence and explanation in British catchments. Quaternary Science Reviews 29(13-14):1555-76.

Matiskainen H. 1989. The chronology of the Finnish Mesolithic. In: Bonsall C, editor. The Mesolithic in Europe. Edinburgh: John Donald. p 379-90.

McColl LJ. 2008. Statistical tools for investigating contemporaneity and co-location in archaeological records [PhD thesis]. School of Mathematics and Statistics, University of Sheffield.

McEvoy BP, Montgomery GW, McRae AF, Ripatti S, Perola M, Spector TD, Cherkas L, Ahmadi KR, Boomsma D, Willemsen G, Hottenga JJ, Pedersen NL, Magnusson PKE, Kyvik KO, Christensen K, Kaprio J, Heikkilä K, Palotie A, Widen E, Muilu J, Syvänen AC, Liljedahl U, Hardiman O, Cronin S, Peltonen L, Martin NG, Visscher PM. 2009. Geographical structure and differential natural selection among North European populations. Genome Research 19:804-14.

Meinander CF. 1984. Kivikautemme väestöhistoria. Suomen väestön esihistorialliset juuret. Bidrag till kännedom av Finlands natur och folk $H$. [Societas Scientarum Fennica] 131:21-48.

Mökkönen T. 2010. Kivikautinen maanviljely Suomessa. Suomen Museo 116:5-38.

Moltchanova E, Rytkönen M, Kousa A, Taskinen O, Tuomilehto J, Karvonen M for the SPAT Study Group and the Finnish Childhood Diabetes Registry Group. 2004. Zinc and nitrate in the ground water and the incidence of type 1 diabetes in Finland. Diabetic Medicine 21:256-61.

Oinonen M, Pesonen P, Tallavaara M. 2010. Archaeological radiocarbon dates for studying the population history in eastern Fennoscandia. Radiocarbon 52(2): 393-407.

Ortman SG, Varien MD, Gripp TL. 2007. Empirical Bayesian methods for archaeological survey data: an application from the Mesa Verde region. American Antiquity 72(2):241-72.

Palo JU, Ulmanen I, Lukka M, Ellonen P, Sajantila A. 2009. Genetic markers and population history: Finland revisited. European Journal of Human Genetics 17:1336-46.

Påsse T, Daniels J. 2011. Comparison between a new and an old semi-empirical Fennoscandian shore-level model. In: Proceedings of the seminar "The Sea Level Displacement and Bedrock Uplift. " Pori, Finland, 10 11 June 2010. Posiva Working Report 2011-07. p 4750.

Pesonen P. 2002. Semisubterranean houses in Finlanda review. In: Ranta, $\mathrm{H}$, editor. Huts and Houses. Stone Age and Early Metal Age Buildings in Finland. Helsinki: National Board of Antiquities. p 9-41.

Pesonen P. 2005. Sarvingin salaisuus - Enon Rahakankaan varhaismesoliittinen ajoitus. Muinaistutkija 2:213.

Pesonen P, Kammonen J, Moltchanova E, Oinonen M, Onkamo P. 2011. Archaeological radiocarbon dates and ancient shorelines - resources and reservoirs. Proceedings of the seminar "The Sea Level Displacement and Bedrock Uplift." Pori, Finland, 10-11 June 2010. Posiva Working Report 2011-07. p 119-29.

Pesonen P, Oinonen M, Carpelan C, Onkamo P. 2012. Early Subneolithic ceramic sequences in eastern Fennoscandia-a Bayesian approach. Radiocarbon, these proceedings.

Pesonen P, Simponen L, Hertell E, Mannermaa K, Nyholm M, Palm J, Rostedt T, Taipale N, Tallavaara M. Forthcoming. First man in the Eastern Finland-a preboreal site with a red ochre grave in Joensuu Rahakangas 1. In: Proceedings of the Meso 2010 Conference, Santander, Spain.

Reimer PJ, Baillie MGL, Bard E, Bayliss A, Beck JW, Bertrand CJH, Blackwell PG, Buck CE, Burr GS, Cutler KB, Damon PE, Edwards RL, Fairbanks RG, Friedrich M, Guilderson TP, Hogg AG, Hughen KA, Kromer B, McCormac G, Manning S, Bronk Ramsey C, Reimer RW, Remmele S, Southon JR, Stuiver M, Talamo S, Taylor FW, van der Plicht J, Weyhenmeyer CE. 2004. IntCal04 terrestrial radiocarbon age calibration, 0-26 cal kyr BP. Radiocarbon 46(3):1029-58.

Reyes AV, Cooke CA. 2011. Northern peatland initiation lagged abrupt increases in deglacial atmospheric $\mathrm{CH}_{4}$. Proceedings of the National Academy of Sciences of the USA 108(12):4748-53.

Saarnisto M. 1971. The history of Finnish lakes and Lake Ladoga. Societas Scientarum Fennica. Commentationes Physico-Mathematicae 41:371-88.

Salmela E, Lappalainen T, Fransson I, Andersen PM, Dahlman-Wright K, Fiebig A, Sistonen P, Savontaus ML, Schreiber S, Kere J, Lahermo P. 2008. Genomewide analysis of single nucleotide polymorphisms uncovers population structure in northern Europe. PlOS ONE 3:e3519.

Shennan S, Edinborough K. 2007. Prehistoric population 
history: from the Late Glacial to the Late Neolithic in Central and Northern Europe. Journal of Archaeological Science 34(8):1339-45.

Sims M, Cox T, Lewison R. 2008. Modeling spatial patterns in fisheries bycatch: improving bycatch maps to aid fisheries management. Ecological Applications 18(3):649-61.

Sundell T, Heger M, Kammonen J, Onkamo P. 2010. Modelling a Neolithic population bottleneck in Finland: a genetic simulation. Fennoscandia Archaeologica XXVII:3-19.

Surovell TA, Brantingham PJ. 2007. A note on the use of temporal frequency distributions in studies of prehistoric demography. Journal of Archaeological Science 34(11):1868-77.

Takala H. 2004. The Ristola site in Lahti and the earliest postglacial settlement of south Finland [PhD thesis]. Turku University.

Tallavaara M, Pesonen P, Oinonen M. 2010. Prehistoric population history in eastern Fennoscandia. Journal of Archaeological Science 37(2):251-60.

Torvinen M. 2000. Säräisniemi 1 Ware. Fennoscandia Archaeologica 17:3-35.

Vuorinen J. 1982. Piikivi ja Suomen kampakeraaminen piikauppa. Moniste / Helsingin yliopiston arkeologian laitos 30 .

Weninger B, Jöris O. 2004. Glacial radiocarbon calibration. The CalPal Program. In: Higham T, Bronk Ramsey C, Owen C, editors. Radiocarbon and Archaeology. Fourth International Symposium, St. Catherine's College, Oxford (9-14 April 2002). Oxford University School of Archaeology. p 9-15. 